\title{
Structural Reforms and CPC Power after the Third CPC Plenum, and the 1st Ses- sion of the 13th NPC
}

\author{
KJELD ERIK BRØDSGAARD AND NIS GRÜNBERG
}

\begin{abstract}
In February and March 2018 the 3rd Plenum of the 19th CPC Congress and the first meeting of the 13th National People's Congress (NPC) were held. During these meetings, important and far-reaching structural reforms were adopted, including constitutional amendments, restructurings of the government and the relationship between Party and state. Structural reforms are common at the outset of a new five-year NPC term, and it is important to understand these reforms as part of an ongoing process. The recent reforms, however, were remarkable in the way they rearranged Party-state relations and bolstered not only the Party but, importantly, Xi Jinping's authority as core leader. This article provides a detailed overview of the major changes in constitution, government structure (ministries and state departments), personnel and Party authority.
\end{abstract}

Keywords: Communist Party of China, Chinese National People's Congress, institutional reform, personnel changes

\section{Introduction}

Four months after the Communist Party of China (CPC) held its 19th Party Congress, the National People's Congress (NPC) convened its annual session. The meeting, which ran from 5 to 20 March 2018, discussed several important issues such as premier Li Keqiang's government report, constitutional amendments, leadership reshuffles and institutional reform.

This article provides an overview of the major decisions and initiatives taken at the NPC meeting. First the main content of the government work report will be presented. The second part of the article focuses on the leadership reshuffle that took place at the meeting. The third part discusses the constitutional amendments that were passed, including the decision to abolish the term limits for the presidency. The fourth part addresses the newest round of institutional reform, which will affect 20 
ministries, being the most ambitious restructuring of the central government structure since Zhu Rongji's reforms in 1998. We will also discuss the strengthening of CPC authority overall, including supervision of discipline and corruption.

\section{Government Work Report}

A major task of the NPC session was to hear and approve the government work report presented by prime minister Li Keqiang (Li 2018a). The report summarized the economic achievements and problems of the past five years and outlined the goals and policies for 2018. The prime minister mentioned that China's gross domestic product (GDP) had risen from 54 trillion to 82.7 trillion $\mathrm{RMB}$, registering average annual growth of 7.1 per cent. The Chinese economy's share of the global economy had grown since 2013 from 11.4 per cent to 15 per cent. China's contribution to global growth had exceeded 30 per cent. Li underlined that the contribution of consumption to growth had increased from 54.9 to 58.8 per cent over the same period and the share of the service sector in the economy had risen to more than 51 per cent, indicating a new more balanced growth path.

As a result of continued economic growth, personal income had increased by 7.4 per cent, outpacing economic growth and creating the world's largest middle-income group. Moreover 68 million people had been lifted out of poverty, bringing the poverty headcount ratio down from 10.2 per cent to 3.1 per cent. Social pension schemes had expanded to cover 900 million people and basic health insurance plans covered 1.35 billion people.

The prime minister also mentioned that China's investment in research and development had grown rapidly and now only ranked second in the world in terms of scale. He listed manned spaceflight, deep-water exploration, quantum communications and large aircraft development as major outcomes of innovation. He added that in e-commerce, mobile payments, the sharing economy and high-speed rail China is now leading the world. Since 2013 China's high-speed railway track expanded from 9,000 to 25,000 kilometers and China now accounts for two-thirds of the world's high-speed railways.

In the work report, Li Keqiang admitted that there were still major problems related to pollution, although the number of days with heavy pollution in major cities had fallen by 50 per cent. There were also still problems of overcapacity, although China had cut steel production 
capacity by more than 170 million metric tons and coal production capacity by 800 million tons.

The work report also outlined the projected targets for economic growth in 2018. The growth rate and inflation rate were set at 6.5 per cent and 3 per cent respectively, the same targets as in 2017. The projected growth rate would create 11 million new jobs and keep the registered urban unemployment rate within 4.5 per cent. A steady rise in import and export volumes were expected, along with a basic equilibrium in the balance of payments. Even though the growth rate still would be significant, the plan was to reduce energy consumption by 3 per cent per unit of GDP.

On poverty alleviation and social welfare, in addition to the 86 million people lifted out of poverty in the past five years, the report stressed that the government would seek to lift another 10 million over the poverty line in 2018 . The government would also increase general transfer payment to local governments by more than 10 per cent in order to strengthen local finances, especially in the western and central regions.

Poverty alleviation was mentioned alongside pollution and risk as one of the 'three critical battles' that the government would continue to be engaged in. The battle against risk involved more coordinated control over the financial sector. Therefore the merger of the China Banking Regulatory Commission (CBCR) and the China Insurance Regulatory Commission (CIRC) came as no surprise. The newly formed entity will report directly to the State Council, while the function of making laws and regulations related to the work of CBRC and CIRC will be handed over to the People's Bank. The much-debated supply-side structural reform also aims to prevent any systemic financial risk in addition to eliminating excessive overcapacity.

The work report and the discussion at the NPC indicate that China has overcome a minor economic slowdown and is not about to experience an economic hard landing. The increase from a growth rate of 6.7 per cent in 2016 to a growth rate of $6.9 \%$ in 2017 shows that the Chinese economy is again on an upward turn. Another positive development is that economic growth appears to have become more balanced. The excessive high investment following the global financial crisis has slowed down by 3 percentage points, causing consumption's share of GDP to rise. In sum, we are seeing early signs of the necessary change in the structure of the Chinese economy towards one that is less unbalanced and more reliant on the consumer demands of the Chinese population (Wolf 2018). 


\section{Personnel Changes}

As expected, the NPC meeting resulted in a major leadership reshuffle at the state level (see Table 1). Also as expected, Xi Jinping was reelected as president and $\mathrm{Li}$ Keqiang as premier. In a surprising move Wang Qishan was elected vice president even though he is no longer a member of the central committee of the CPC. Even more surprising was the decision to remove the two-term limits for president and vice president. This clears the way for $\mathrm{Xi}$ to stay in power indefinitely. Chinese sources claim that this was not the main objective of the constitutional amendment passed on 11 March. Rather, the objective is to bring the Chinese presidency's institutional mechanics in line with the office of the general secretary and the chairmanship of the Central Military Commission, where no term limits apply (Li 2018b).

Leading up to the 19th Party Congress in October 2017, there was much speculation about the future political role of Wang Qishan. Many observers of Chinese politics posited that he might continue on the Politburo Standing Committee. However, as Wang Qishan had turned 69 in July 2017, this would violate the unwritten rule of '68 down, 67 up' (Brødsgaard and Christensen 2017). In the end this rule was upheld and Wang Qishan was retired from all his Party positions and was not reelected to the Central Committee. But Wang Qishan's appointment as vice president gives him a new and important political role. Given his extensive experience and close relationship to $\mathrm{Xi}$, it is unlikely that his vice presidency is a ceremonial role like that of most of his predecessors. Although his portfolio in the Politburo Standing Committee was to direct the anti-corruption campaign, he has an extensive background in economics and diplomacy and has previously been in charge of the strategic dialogue between the USA and China. $\mathrm{He}$ will be an important asset for $\mathrm{Xi}$ in handling the difficult relationship with the USA.

At the NPC meeting Li Zhanshu took over Zhang Dejiang's role as NPC Chairman. This was expected as the number three in the Party hierarchy, except in the case of Li Peng, normally functions as head of the NPC. Similarly, Wang Yang, in his capacity as number four in the Party hierarchy, succeeded Yu Zhengsheng as Chairman of the Chinese People's Political Consultative Conference (CPPCC). In the case of Wang Yang this may seem like a waste of talent as he is regarded as an efficient economic administrator and might be of more use as vice premier in charge of economic work. 
TABLE 1. The Chinese government (March 2018)

\begin{tabular}{|c|c|c|}
\hline Ministry & Minister & \\
\hline Foreign Affairs & Wang Yi & 王毅 \\
\hline National Defence & Wei Fenghe & 魏凤和* \\
\hline $\begin{array}{l}\text { National Development and Reform } \\
\text { Commission (NDRC) }\end{array}$ & He Lifeng & 何立峰 \\
\hline Education & Chen Baosheng & 陈宝生 \\
\hline Science and Technology (R) & Wang Zhigang & 王志刚* \\
\hline Industry and Information Technology & Miao Wei & 苗圩 \\
\hline State Ethnic Affairs Commission & Bater & 巴特尔 \\
\hline Public Security & Zhao Kezhi & 赵克志 \\
\hline State Security & Chen Wenging & 陈文清 \\
\hline Civil Affairs & Huang Shuxian & 黄树贤 \\
\hline Justice (R) & Fu Zhenghua & 傅政华* \\
\hline Finance & Liu Kun & 刘昆)* \\
\hline Human Resources and Social Security & Zhang Jinan & 张纪南* \\
\hline Natural Resources ${ }^{* *}$ & Lu Hao & 陆昊* \\
\hline Ecological Environment ${ }^{* *}$ & Li Ganjie & 李干杰 \\
\hline $\begin{array}{c}\text { Housing and Urban-Rural Develop- } \\
\text { ment }\end{array}$ & Wang Menghui & 王蒙徽 \\
\hline Transport & Li Xiaopeng & 李小鹏 \\
\hline Water Resources & E Jingping & 鄂竟平* \\
\hline Agriculture and Rural Affairs ${ }^{* *}$ & Han Changfu & 韩长赋 \\
\hline Commerce & Zhong Shan & 钟山 \\
\hline Culture and Tourism ${ }^{* *}$ & Luo Shugang & 雒树刚 \\
\hline National Health Commission ${ }^{* *}$ & Ma Xiaowei & 马晓伟* \\
\hline Veterans Affairs ${ }^{* *}$ & Sun Shaocheng & 孙绍骋* \\
\hline Emergency Management** & Wang Yupu & 王玉普* \\
\hline People's Bank of China & Yi Gang & 易纲* \\
\hline National Audit Office & Hu Zejun & 胡泽君 \\
\hline
\end{tabular}

* New ministers

** New ministries established

Leading up to the NPC there was widespread speculation and discussion concerning the anticipated formation of a new 'super' anti-graft agency in the form of a National Supervision Commission (NSC). As expected, the NSC was introduced as a new type of state organ in the amended constitution. The new commission was formed from the merger of the Ministry of Supervision and National Bureau of Corruption under the State Council, and the Office Against Dereliction of Duty and Anti-Corruption Department of the Procuratorate. It was ranked above the Supreme Court and Supreme Procuratorate, but below the 
central government. Yang Xiaodu, Politburo member and deputy head of the Party's Central Discipline and Inspection Commission (CDIC), was appointed head of the NSC. The new commission was formed to consolidate all activities of anti-graft institutions and to legitimate extralegal investigations of public officials under the name of 'rule of law'. This includes managers of state-owned enterprises (SOEs), hospitals, educational and cultural educations, sports organizations and even village governments and research institutes. Top leadership felt a need to establish the new agency due to the fact that, in principle, the CDIC can only investigate corruption and graft among Party members and not all public officials are members of the CPC. However, with the appointment of Yang Xiaodu, who as deputy is ranked lower than the head of the CDIC, Politburo Standing Committee member Zhao Leji, it is clear that the activities of the new commission will be coordinated and overseen by the Party.

Han Zheng, Sun Chunlan, Hu Chunhua and Liu He were all endorsed by the NPC as vice premiers. Given the fact that Han Zheng is the lowest ranking of the seven Standing Committee members it was expected he would take over Zhang Gaoli's portfolio. Sun Chunlan had a long career as Party secretary in Fujian and Tianjin before she became head of the United Front Department in 2014. She is the only women at the top level of government and in fact also the only woman in the Politburo. $\mathrm{Hu}$ Chunhua has extensive provincial experiences as Party secretary in Chongqing and Guangdong and has also served as first secretary of the Youth League. He has long been rumored as one of the top candidates to succeed $\mathrm{Xi}$, if he steps down in 2022. In Xi's eyes $\mathrm{Hu}$ is handicapped by his close association with the Youth League and his reformist tendencies. However, as one of the four vice premiers he still has a chance to advance to the Standing Committee at the 20th Party Congress. Liu He is $\mathrm{X}$ Jinping's right-hand man in economic affairs and he runs the office of the important economic and finance leading small group. Among the vice premiers he is likely to outshine Han Zheng.

State Councillors were also almost completely replaced, except for Wang Yong. The new State Councillors are Wei Fenghe, member of Central Military Commission and minister of National Defence, Xiao Jie, secretary-general of the State Council and former minister of Finance, Zhao Kezhi, minister of Public Security and former Party secretary of Hebei, and, finally, foreign minister Wang Yi. He replaces former foreign minister Yang Jiechi, who has been promoted to the Politburo. 
Among the 27 ministers there were 11 new faces. These include Yi Gang, who replaces Zhou Xaochuan as Governor of the People's Bank of China. Yi Gang has been deputy governor of the bank since 2008, so his appointment is not expected to bring any major change to Zhou Xiaochuan's monetary policies in attempting to leverage the massive debt and manage financial risks. Among the new ministers, there are also two former business executives from the oil and gas sector: Minister of Science and Technology, Wang Zhigang, who is former senior vice president of Sinopec, and Minister of Emergency Management, Wang Yupu, who is former general manager of Petro China. Three other members, who have a background in the SOE sector, include Minister of Transportation, Li Xiaoping, who has served as chairman of Huaneng Power Corporation, and the Minister of Information Technology, Miao Wei, who is former general manager of Dongfeng Auto Corporation. The fifth minister, with a business background, is the Minister of Commerce, Zhong Shan, who was general manager of Zhejiang Zhongda Group Limited before shifting to government work. These examples show the close relationship between big business and government/Party in China. This is also the case at the provincial level where one-fifth of all China's governors and vice governors have a background in business.

At 65, Wang Yi and Zhao Kezhi are the two oldest members of the State Council; at 50, Lu Hao is the youngest. Lu Hao was appointed first secretary of the Youth League in 2008 and thus already gained ministerial rank at the age of 40. In 2013 he was moved to Heilongiiang to become governor. His relatively young age combined with both provincial and central leadership experiences will provide a good background for moving further up the Party hierarchy. However, his affiliation with the Youth League and Li Keqiang may not be an advantage in the eyes of $\mathrm{Xi}$ Jinping.

\section{Constitutional Amendments}

One of the decisions of the NPC that has received most attention, and criticism, is the range of amendments to the state constitution. ${ }^{1}$ It was decided to scrap term limits for the President that were added to the constitution in 1982, and which so far had been limited to two terms of five years. But this was only one of 21 amendments made, all of which were proposed at a CPC Central Committee meeting in February (Xinhua 2018), and overall these amendments reflect the general trend of a stronger Party around Xi Jinping as core leader. Important amendments 
were made in the preamble of the constitution, which is where China's development is historicized and the CPC's reading of its role as ruling Party is outlined. The preamble now includes a reference to Hu Jintao's theoretic-ideological contribution, the 'Scientific Outlook on Development', but, more importantly, it also contains Xi Jinping's contribution. This is unusual, as both Jiang Zemin and Hu Jintao were only 'constitutionalized' only after they had stepped down. Undoubtedly, this both shows and is proof of $\mathrm{Xi}$ Jinping's authority as leader and his resolve to push his vision for China's development.

With the addition of "Xi Jinping thought on Socialism with Chinese Characteristics for a new era", $\mathrm{Xi}$ has not only been elevated to the standing of former Party leaders, but in fact has also been set apart from his predecessors. Using the term 'thought' (sixiang) for his theoretical-ideological programme, places him on a level with Mao Zedong's thought, and thus gives his ideas more weight than even Deng Xiaoping's 'theory' (lilun). Moreover, the term 'for a new era' points at a break from Dengist times and a shift towards a more assertive (at least more proactive) international profile, which legitimizes $\mathrm{Xi}$ 's turn towards a much more authoritative, Party-centered governance of China domestically. This was already hinted at in earlier speeches by $\mathrm{Xi}$, where he talked about China's 'three thirty years periods', meaning the periods under Mao, Deng and now himself. Concepts introduced under Deng such as 'separation of Party and government' are, in other words, out of fashion, and the 'new era' is marked, in Wang Qishan's words, by a 'division of labour' between Party and state, with the Party clearly in charge.

While Xi Jinping has been cemented as the core leader, the Party's status as the supreme leading institution has more generally been underscored by the amendments. Article 1 was changed from 'The socialist system is the basic system of the People's Republic of China' to 'The defining feature of socialism with Chinese characteristics is the leadership of the Communist Party of China'. This puts the CPC into the main body of the constitution, whereas previously it was only mentioned in the preamble. Article 24 was changed to include the 'core socialist values' as primary objectives of the state, another concept favoured by Xi Jinping, and now constitutionalized. Government officials now are required to take an oath to the constitution (article 27), a practice that was until then common only in the Party, where new members take an oath to the Party constitution.

Two further amendments worth noting are related to the new State Supervision Commission (SSC), which is now mentioned several times, 
and its position as primary supervision body (albeit under the Party's watchdog, the CCDI). The amended Constitution also specifies details of the new body, among others granting authority to elect the chairperson of the SSC to the NPC. At the same time, the changes also strip away supervision authorities from the State Council, as they now lie within the SSC.

Finally, another important policy area pushed by Xi Jinping has found its way into the constitution, with the addition of the 'State Council function and power to (...) the building of an ecological civilization'. This means that environmental affairs now are a responsibility of the State Council, underscoring the importance the $\mathrm{Xi}$ administration attaches to climate change and pollution issues (see also below).

\section{Ambitious Institutional Reform}

The NPC meeting decided on an ambitious institutional reform (jigou gaige) affecting over 20 ministries and commissions in the State Council. While restructuring during NPC congresses are common, this round turned out to be quite a substantial reshuffle of authorities, consolidation of new, powerful organs, and a strong trend to closely integrate and realign the state apparatus under CPC authority (Xinhua 2018). It is important to note that the meetings of the NPC were preceded by a Party meeting (the 3rd Plenum of the 19th CPC Congress), announcing changes to the organizational structure of the central state and Party only days before the NPC meeting (CPC 2018). Seen from a broader perspective, this newest round of institutional reforms is clearly meant to bolster CPC authority over and within the state apparatus

With interim periods of about five years - that is, in 1982, 1988, 1993, 1998, 2003, 2008 and 2013 - the Chinese leadership has implemented such reform in an attempt to streamline and downsize the bureaucracy in order to make it more efficient. The last restructuring of a similar large scale took place in 1998 when Zhu Rongji merged or closed 15 ministries and commissions under the State Council. This time the reshuffle also aims to consolidate Party leadership over the state apparatus.

The 1998 administrative reform reduced the number of ministerial-level working departments of the State Council from 41 to 29 and downsized central-level staff of the State Council from 32,000 to 16,000 (Brødsgaard 2002). A number of the old branch ministries in the machinery and heavy-industrial sector, which had existed since the Soviet-style planning system was introduced in the early 1950s, were organized into 
bureaus, thereby losing their ministerial-level status. Other ministries were merged such as the Ministry of Electrical Industry, the Ministry of Post and Communications and the Ministry of Radio, Film and Television. Their functions and personnel were transferred to a new Ministry of Information Industry.

In 2003 a new, but less dramatic, reform of the administrative reform was carried out. This involved the establishment of a new State-Owned Asset Supervisory and Administration Commission in order to have a ministerial-level agency that could supervise and manage the large SOEs. Moreover, the State Development Planning Commission was restructured into a new body, the National Development and Reform Commission (NDRC) and a Ministry of Commerce was re-established. Finally, existing financial regulatory bodies were reorganized into the People's Bank of China, China Banking Regulatory Commission and China Insurance Regulatory Commission. As a result, there were 28 ministries and commissions under the State Council (Liu 2008).

However, the Chinese government continued to be concerned about the administrative structure at the central level. There were voices arguing for further streamlining of administrative organs as well as personnel. In 2008 a new plan for institutional reform of the state administrative apparatus was adopted under the headline of 'a system of larger ministries' (da bumen tizhi) within areas of priority. The goal was to create a number of strong ministries that would bring together related functional areas. Subsequently five new superministries were established. They were the Ministry of Industry and Information, the Ministry of Human Resources and Social Security, the Ministry of Transport, the Ministry of Housing and Urban-Rural Construction, and the Ministry of Environmental Protection. However, the powerful Ministry of Railway managed to keep its independent status in light of 'the consideration of the special needs' in managing the railways.

The 2008 reorganization affected 15 government organs and reduced the number of ministries and commissions from 28 to 27 - three of these were commissions (Renmin ribao 2008). This was a less substantial downsizing and reorganization than originally anticipated. It had, for example, not been possible to merge the Ministry of Railway with the new Ministry of Transportation. Powerful interests were against the merger since it would downgrade the importance of the railways in China's transportation system. In a similar way, entrenched interests were able to block the idea of creating a Ministry of Energy. 
In 2013, it finally became possible to abolish the Ministry of Railway and merge its administrative functions with the Ministry of Transportation and transfer its commercial activities to a new SOE. The 2013 reshuffle also involved several mergers such as a merger of the Ministry of Health and the Family Planning Commission, a merger of the State Food and Drug Administration and the State Commission on Food Safety, a merger of the Administration of Press and Publication and the State Administration of News, Broadcasting, Film and Television (Brødsgaard and Grünberg 2013). It was also decided to create a more comprehensive administration of maritime issues. However, it was still not possible to establish a new Ministry of Energy.

All these restructurings and reshuffles involved intense turf wars between the various ministries and agencies. Essentially it is a question of positions and budget as specified in the bianzhi system (Brødsgaard 2002). Every institutional reform is based on san ding. This concept has three dimensions. The first is to determine the functions needed in a given government organ (ding zhineng). The second dimension of the concept is to fix the number of administrative organs (ding jiguan) on the basis of the defined core functions. The third aspect is about determining the number of personnel (ding renyuan). This is done on the basis of the functions and administrative organs that have been deemed necessary to uphold. Administrative organs will be allocated personnel according to the functions and tasks they are supposed to take care of.

The current revamping of the central government structure is based on the san ding exercise, which involves tough inter-bureaucratic bargaining. However, this time the reform is different: it's not only about creating a leaner and more efficient government system, it is also about strengthening the Party's control over the government. In this sense, it is yet another example of the current leadership's intention to no longer to follow Deng Xiaoping's policy of separating Party and government.

Overall, the NPC reduced the number of ministry-level organizations by eight, and the State Council now includes 26 ministries, seven of them newly established from reassigned authorities (see Table 2).

\section{Revamping of Central Government}

An important part of the 2018 restructuring is the consolidation and strengthening of ministries and departments in charge of environmental and natural resource management issues. This was to be expected, as environmental protection and green development have been priorities 
TABLE 2. State Leaders in China (March 2018)

\begin{tabular}{|l|l|l|}
\hline President & Xi Jinping & 习近平 \\
\hline Vicepresident & Wang Qishan & 王岐山 \\
\hline NPC chairman & Li Zhanshu & 栗战书 \\
\hline CPPCC chairman & Wang Yang & 汪洋 \\
\hline Premier & Li Keqiang & 李克强 \\
\hline \multirow{5}{*}{ Vicepremiers } & Han Zheng & 韩正 \\
\cline { 2 - 3 } & Sun Chunlan & 孙春兰 \\
\cline { 2 - 3 } & Hu Chunhua & 胡春华 \\
\cline { 2 - 3 } & Liu He & 刘鹤 \\
\hline \multirow{5}{*}{ State councillors } & Wei Fenghe & 魏凤和 \\
\cline { 2 - 3 } & Wang Yong & 王勇 \\
\cline { 2 - 3 } & Wang Yi & 王毅 \\
\cline { 2 - 3 } & Xiao Jie & 肖捷 \\
\cline { 2 - 3 } & Zhao Kezhi & 赵克志 \\
\hline CMC chairman & Xi Jingping & 近平 \\
\hline \multirow{2}{*}{ CMC vice chairmen } & Xu Qilang & 许其亮 \\
\cline { 2 - 3 } & Zhang Youxia & 张又侠 \\
\hline Head of National Supervisory Commission & Yang Xiaodu & 杨晓渡 \\
\hline
\end{tabular}

under Xi Jinping for some time. As early as December 2016, the Environmental Protection Law was promulgated, with tougher regulation and harsher penalties for transgressions, and more authority vested in local environmental protection bureaucracy, which came into effect on 1 January 2018. A 'war against pollution' declared in 2014 is beginning to show effects, for example with less air pollution in Beijing, ${ }^{2}$ and ever since the programmatic 'ecological civilization' was written into top-level policy at the third Plenum of the 18th CPC Congress in November 2013, environment and resource conservation policy have been underscored as important areas for leaders, also at local levels (State Council 2014: 56). Responsibility for coordinating ecological civilization related policies had in 2013 been assigned to the powerful Leading Small Group for Comprehensively Deepening Reform's sub-group for economic development and ecological civilization, headed by Liu He, a sign that, at least at a conceptual level, growth and environment were now seen as connected areas. Furthermore, the current five-year plan (2016-2020) boasts a relatively large section on 'ecosystems and environment', and this overall trend towards a greener and 'beautiful China' has now been underpinned by structural reforms in the central administration.

A new Ministry of Ecological Environment has absorbed several functions and organizations, among others the former Ministry of Environ- 
mental Protection, the climate change and carbon reduction authorities of the NDRC (including the Leading Small Groups for climate change and emission reduction work), and pollution controlling functions of, among others, the Ministries of Agriculture, Water Resources, and Land and Resources. The new Ministry of Natural Resources has taken over the responsibilities of a number of organizations, chiefly the Ministry of Land and Resources (abolished), NDRC planning authorities, the State Oceanic Administration (abolished), the Ministry of Water Resources, and others. This new ministry has a more consolidated mandate to administrate and plan natural resources including land, and by gathering these responsibilities in one organization, solves fragmentation issues that had hampered policy implementation across jurisdictions. Lastly, a newly established Ministry of Emergency Management has taken over a number of responsibilities and is charged with reacting to and preventing environmental (as well as social) disasters and crises, such as drought, wildfire prevention and floods, all functions formerly embedded in separate ministries and administrations.

These changes clearly make sense from a perspective of consolidating authorities over resource, land and environmental protection policy respectively in one organization. Management of water and land resources, for example, was previously hampered by the fact that jurisdictional boundaries made coordinated policy difficult. The new Ministry of Ecological Environment is a clear indicator that the $\mathrm{Xi}$ administration aims to live up to the promises of a greener and cleaner China, and has now given formal, administrative authority to the stricter laws and standards set over the last five years of the $\mathrm{Xi}$ administration.

Other changes that deserve mentioning are that the Ministry of Agriculture has expanded its portfolio and has had its name changed to Ministry of Agriculture and Rural Affairs. A new Ministry of Veteran Affairs has been created, which takes over functions from the Ministry of Human Resources and Social Security, the NDRC and even from the Central Military Commission. The new Ministry of Culture and Tourism is based on a merger of the former Ministry of Culture and the National Tourism Bureau.

The newly created National Health Commission, which to a large degree is identical with the abolished National Health and Family Planning Commission, will target the issue of population ageing and stimulate the development of age-old industries and services. It is expected that by 2030 a quarter of China's population will be 60 years old and older. 


\section{Regulating Finance}

Since 2009, the fallout from the stimulus packages launched in reaction to the financial crisis of 2008/09 has begun to show, in form of non-performing loans, overcapacity and unsustainable government spending, especially at local levels and in the state-owned sector. Furthermore, financial services and capital investment by both public and private actors have grown rapidly, and Chinese financial services are increasingly pushing for new markets, both domestic and international. These developments and a number of shortcomings in the regulatory structure have now led to efforts strengthening the regulation and leadership of banking and finance.

Structurally, the NPC decided to merge the China Banking Regulatory and the Insurance Regulatory Commissions into the new China Banking and Insurance Regulatory Commission. Moreover, 'upgrading' the Leading Small Group for Finance and Economy (LSGFE) to commission gives the Party stronger macro control over financial policy.

China's central bank, the People's Bank of China, now is under a strong double leadership team. Yi Gang replaced Zhou Xiaochuan as governor of the bank, while Guo Shuqing serves as the bank's Party secretary. Both are highly capable and experienced officials, with prior positions in financial institutions. Yi Gang holds an American PhD degree, and has published numerous academic articles and books on economics. There has been speculation about the exact division of labour between the two leaders, and Chinese official media have reported that Guo, as Party secretary, will be overseeing the bank's most important and strategic decisions, while Yi Gang will be in charge of its daily operations. Moreover, Guo also serves as Party secretary of the aforementioned Banking and Insurance Regulatory Commission. Liu Shiyu has taken over leadership of the China Securities Regulatory Commission, and together with Guo and $\mathrm{Yi}$, Chinese media have dubbed this new team the 'new three-horse chariot' leading China's financial regulatory regime. After a number of cases of financial instability, debt issues in the stateowned sector, and excessive investment in both state-owned as well as private companies (some recent high-profile cases are Anbang and HNA Group), it became clear that the Xi administration would consolidate financial watchdogs and banking. 


\section{The Party Widens its Mandate}

Overall, it has become manifest that Xi Jinping has been pushing the strengthening and broadening of the CPC's leadership mandate over China in ways that have surprised most, if not all China watchers, and even many people in China. Party leadership and its superiority visà-vis the state is nothing new in itself, but it is being formalized and institutionalized at a pace and scale unseen after 1978. The new, consolidated Party is not merely 'leading China', as defined in both state and Party constitutions, but its rule is underscored by the restructuring plan adopted at the 3rd Plenum (CPC 2018). The plan points out that: 'Party, government, military, the people, and education, the East, the West, the South, the North, and the Center, the Party is the leader of everything'. ${ }^{3}$

A significant indication of the broadening of Party authority is the reorganization of the State Administration for Public Service under the Party's Central Organization Department (COD). This is the bureau in charge of the civil servants, which used to be part of the Ministry of Human Resources and Social Security. The bianzhi administration, the office in charge of planning and allocating personnel and organizational resources, was also put under the COD. This means that the Party is now effectively in charge of all human resource allocations, including for nonParty organizations and public servants who are not Party members.

The media has always been under supervision in China, but the CPC's control has been tightened in this round of restructuring. The State Administration of Press, Publication, Radio, Film and Television was disbanded and its function divided into three organizations. One of these, the new State Administration of Radio and Television, remains under the State Council, but the two other new administrations, one for Film, and one for Press and Publication, are now under the CPC Publicity Department (Propaganda Department). Moreover, the China Publishing Group, a state-owned publishing house until now under the State Council, will also fall under the supervision of the Publicity Department. This means that media content will increasingly be directly controlled by the CPC and the Party's narrative will become even more dominant in all media. Indeed, in official documents the media sector is referred to as the 'ideological sector', implying the functionality the CPC sees in media and its use for political means.

The Party's control over strategic policymaking and coordination has been enhanced and formalized by the upgrading of four important 
Leading Small Groups (LSGs) into Commissions. These LSGs are the LSG for Comprehensively Deepening Reforms, Finance and Economy, Foreign Affairs, and the LSG for Cybersecurity and Informatization. This change of status from LSG represents a formalization of central institutions in the Party-state and signals a consolidation of their formal authority in coordinating these important policy areas.

\section{Conclusion}

Overall, the 3rd Party Plenum of February and the 1st Session of the 13th NPC in March have been remarkable in several ways. As we have outlined above, Xi Jinping has not only consolidated himself as the core leader, but he has been able to include his agenda into the state constitution. Moreover, under Xi the Party has been strengthened quite remarkably, and even taken steps back from the (feeble) separation of state and Party organizations undertaken under Deng Xiaoping. The $\mathrm{CPC}$ under $\mathrm{Xi}$ Jinping has in in every aspect widened its mandate and its grasp over the state apparatus, its personnel and society at large. At the same time, supervision and anti-corruption efforts are institutionalized and formalized, and Xi's programme for a clean and loyal Party, including harsh methods to ensure loyalty and punish transgressions, has been made a central element of the Party-state. An ambitious institutional reform of ministries and bureaus under the State Council has been introduced, affecting more than 20 ministries and commissions. Regulation of economy and finance has been consolidated and green development underscored as a key priority. Initiating and overseeing these developments is a powerful state and Party leader who has succeeded in abolishing term limits for leadership position and having his name written into both the Party and the state constitution.

KJELD ERIK BRØDSGAARD is Professor at the Department of International Economics and Management, and the Director of the China Policy Program at Copenhagen Business School (CBS).Email:keb.int@cbs.dk

NIS GRÜNBERG is a postdoctoral researcher at the Department of International Economics and Management, CBS, and the Sino Danish University Centre for Research and Education.Email:ng.int@cbs.dk 
Kjeld Erik Brødsgaard and Nis Grünberg

\section{NOTES}

1 The Chinese Constitution is available at: http://www.npc.gov.cn/englishnpc/Constitution/node_2825.htm.

2 https://www.nytimes.com/2018/03/12/upshot/china-pollution-environmentlonger-lives.html.

3 Original text: 党政军民学, 东西南北中, 党是领导一切的.

\section{REFERENCES}

Brødsgaard, Kjeld Erik 2002. 'Institutional Reform and the Bianzhi System in China'. China Quarterly 170 (June): 361-386. https:/ / doi.org/10.1017/S0009443902000232.

Brødsgaard, Kjeld Erik and Nis Grünberg 2013. 'Leadership Changes and Structural Reform after the 18th Party Congress in China'. Copenhagen Journal of Asian Studies 31 (1): 81-94.

Brødsgaard, Kjeld Erik and Nis Høyrup Christensen 2017. 'The 19th Party Congress: Personnel Changes and Policy Guidelines'. Copenhagen Journal of Asian Studies 35 (2): 79-97.

CPC 2018. Shenhua dang he guojia jigou gaige (Plan for Reform Deepening of Party and State Structure). Available at: http://www.gov.cn/zhengce/2018-03/21/content_5276191.htm\#1. Accessed 10 May 2018.

Li, Keqiang 2018a. 'Zhengfu gongzuo baogao - 2018 nian san yue wu ri zai dishisan jie quanguo renmin daibiao dahui diyici huiyi shang' (Government Work Report - Delivered at the First Session of the 13th National People's Congress, 5 March). Available at: http://www.xinhuanet.com/politics/2018lh/2018-03/22/c_1122575588. htm. Accessed 10 May 2018.

Li, Eric 2018b. 'Why Xi's Lifting of Term Limits is a Good Thing'. The Washington Post, 2 April. Available at: https://www.washingtonpost.com/news/theworldpost/ wp $/ 2018 / 04 / 02 / x i$-term-limits $/$ ?noredirect=on\&utm_term $=.51$ cfefbac3eb. Accessed 10 May 2018.

Liu, Jen-Kai. 2008. 'Eine neue Runde der Strukturreform des Staatsrats'. China aktuell - Journal of Current Chinese Affairs 2: 140-156.

NPC 2018. Constitution of the People's Republic of China. Available at: http:/ / www.npc. gov.cn/englishnpc/Constitution/node_2825.htm. Accessed 10 May 2018.

NPC Observer 2018. 'A Guide to 2018 State Council Institutional Reforms.' Available at: https://npcobserver.com/2018/03/14/a-guide-to-2018-state-council-institutionalreforms/. Accessed 10 May 2018.

Renmin ribao (People's Daily) 2008. 'Xin yilun guowuyuan jigou gaige qidong.' The Launch of a New Round of State Council Institutional Reform). Renmin ribao, 12 March.

State Council 2014. Document 56 Guowuyuan bangongting guanyu jiaqiang huanjing jianguan zhifa de tongshi (State Council General Office Notice on the Strengthening of the Implementation of Environmental Supervision and Regulation). Available at: http://www.gov.cn/zhengce/content/2014-11/27/content_9273.htm. Accessed 8 May 2018.

Wolf, Martin 2018. 'The Chinese Economy is Rebalancing at Last'. Financial Times, 3 April. Available at: https://www.ft.com/content/b54cda40-3659-11e8-8b982f31af407cc8. Accessed 5 May 2018.

Xinhua (2018). 'Guowuyuan jigou gaige fangan' (State Council Institutional Restructuring Plan). Available at: http:/ / www.gov.cn/xinwen/2018-03/17/content_5275116 htm. Accessed 8 May 2018. 
TABLE 3. China's Government (March 2018)

\begin{tabular}{|c|c|}
\hline \multicolumn{2}{|r|}{ New Ministries } \\
\hline New & Functions taken over from \\
\hline \multirow{5}{*}{$\begin{array}{l}\text { Ministry of Ecological } \\
\text { Environment }\end{array}$} & $\begin{array}{c}\text { Ministry of Environmental Protection } \\
\text { (replaced) }\end{array}$ \\
\hline & $\begin{array}{l}\text { National Development and Reform } \\
\text { Commission (NDRC) (climate change) }\end{array}$ \\
\hline & $\begin{array}{l}\text { Ministry of Land and Resources } \\
\text { (water pollution) }\end{array}$ \\
\hline & Ministry of Agriculture (pollution) \\
\hline & $\begin{array}{l}\text { State Oceanic Administration } \\
\text { (Ocean pollution) }\end{array}$ \\
\hline $\begin{array}{l}\text { Ministry of Agriculture } \\
\text { and Rural Affairs }\end{array}$ & Ministry of Agriculture (replaced) \\
\hline $\begin{array}{l}\text { Ministry of Culture } \\
\text { and Tourism }\end{array}$ & $\begin{array}{c}\text { Merger of the Ministry of Culture and } \\
\text { National Tourism Bureau }\end{array}$ \\
\hline $\begin{array}{c}\text { Ministry of Veterans } \\
\text { Affairs }\end{array}$ & $\begin{array}{l}\text { Ministry of Civil Affairs, Ministry of Hu- } \\
\text { man Resources and Social Security, and } \\
\text { the Central Military Commission }\end{array}$ \\
\hline \multirow{3}{*}{$\begin{array}{l}\text { Ministry of Natural } \\
\text { Resources }\end{array}$} & $\begin{array}{c}\text { Ministry of Land and Resources } \\
\text { (replaced) }\end{array}$ \\
\hline & State Oceanic Administration \\
\hline & National Surveying and Mapping Bureau \\
\hline \multirow{2}{*}{$\begin{array}{l}\text { National Health } \\
\text { Commission }\end{array}$} & $\begin{array}{l}\text { National Health and Family Planning } \\
\text { Commission (replaced) }\end{array}$ \\
\hline & $\begin{array}{l}\text { The medical and health-care reform } \\
\text { leading small group under the State } \\
\text { Council (dissolved) }\end{array}$ \\
\hline $\begin{array}{l}\text { Ministry of Emergency } \\
\text { Management }\end{array}$ & $\begin{array}{c}\text { National Safety Production Supervision } \\
\text { Management Bureau (replaced). }\end{array}$ \\
\hline
\end{tabular}


TABLE 4. List of Ministries and Commissions under the State Council after the Restructuring

\section{Abolished ministries}

Ministry of Agriculture

Ministry of Culture

Ministry of Environmental Protection

Ministry of Land and Resources

Ministry of Supervision

National Health and Family Planning Commission

\section{New Ministries}

Ministry of Natural Resources

Ministry of Ecological Environment

Ministry of Culture and Tourism

National Health Commission

Ministry of Agriculture and Rural Affairs

Ministry of Veterans Affairs

Ministry of Emergency Management

\section{Retained ministries}

Ministry of Foreign Affairs

Ministry of National Defense

National Development and Reform Commission

Ministry of Education

Ministry of Science and Technology

Ministry of Industry and Information Technology

State Ethnic Affairs Commission

Ministry of Public Security

Ministry of State Security

Ministry of Civil Affairs

Ministry of Justice

Ministry of Finance

Ministry of Human Resources and Social Security

Ministry of Housing and Urban-Rural Development

Ministry of Transport

Ministry of Water Resources

Ministry of Commerce

People's Bank of China

National Audit Office 


\section{Changes to Administrations under the State Council}

\section{Abolished Administrations}

China Food and Drug Administration

General Administration of Quality Supervision, Inspection, and Quarantine

National Bureau of Corruption Prevention

National Tourism Administration

State Administration for Industry and Commerce

State Administration of Press, Publication, Radio, Film and Television State Administration of Work Safety

State Forestry Administration

Legislative Affairs Office of the State Council

China Banking Regulatory Commission

China Insurance Regulatory Commission

National Administration of Surveying, Mapping and Geoinformation State Administration of Foreign Experts Affairs

State Administration of Grain

State Oceanic Administration

\section{Newly Established Administrations}

State Drug Administration

State Forestry and Grassland Administration/National Park

Administration

State Grain and Reserves Administration

State Immigration Administration

State Administration of Radio and Television

State International Development Cooperation Agency

State Medical Insurance Administration

State Market Regulatory Administration

China Banking and Insurance Regulatory Commission Source: NPC Observer (2018). 